\title{
EXPLAINING ISLAMIST INSURGENCIES
}

The Case of al-Jamaah al-Islamiyyah and the Radicalisation of the Poso Conflict, 2000-2007 


\section{Imperial College Press Insurgency and Terrorism Series}

ISSN: $2335-6847$

Series Editor: Rohan Gunaratna (Nanyang Technological University,

Singapore)

Published

Vol. 1 Countering Extremism: Building Social Resilience through

Community Engagement

edited by R. Gunaratna, J. Jerard and S. M. Nasir

Vol. 2 The Father of Jihad: 'Abd Allah Azzam's Jihad Ideas and Implications to National Security

by Muhammad Haniff Hassan

Vol. 3 Explaining Islamist Insurgencies: The Case of al-Jammah al-Islamiyyah and the Radicalisation of the Poso Conflict, 2000-2007 by Muhammad Tito Karnavian

Forthcoming

Wars from Within: Understanding and Managing Insurgent Movements by Albrecht Schnabel (Geneva Centre for the Democratic Control of Armed Forces) and Rohan Gunaratna (Nanyang Technological University, Singapore)

The Roots of Religious Extremism: Understanding the Salafi Doctrine of Al-Wala' Wal Bara'

by Mohamed Bin Ali (Nanyang Technological University, Singapore)

Cultural Security: Evaluating the Power of Culture in International Affairs by Erik Nemeth (Rand Corporation, USA) 


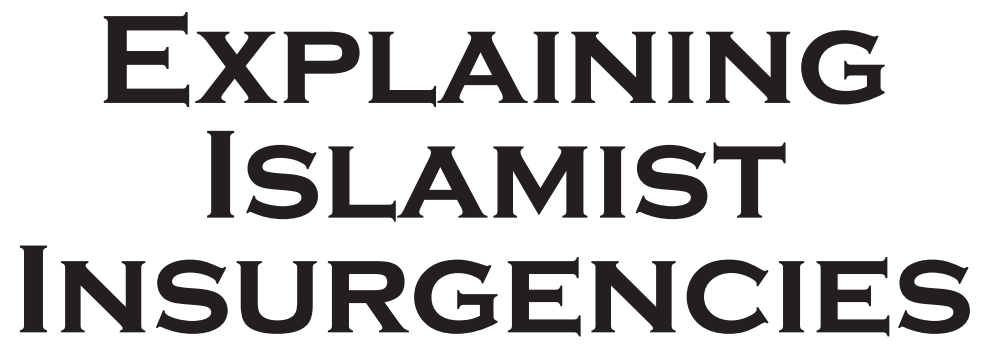

The Case of al-Jamaah al-Islamiyyah and the Radicalisation of the Poso Conflict, 2000-2007

\section{Muhammad Tito Karnavian}

S. Rajaratnam School of International Studies Nanyang Technological University, Singapore 


\section{Published by}

Imperial College Press

57 Shelton Street

Covent Garden

London WC2H 9HE

\section{Distributed by}

World Scientific Publishing Co. Pte. Ltd.

5 Toh Tuck Link, Singapore 596224

USA office: 27 Warren Street, Suite 401-402, Hackensack, NJ 07601

UK office: 57 Shelton Street, Covent Garden, London WC2H 9HE

\section{Library of Congress Cataloging-in-Publication Data}

Karnavian, M. Tito, author.

Explaining Islamist insurgencies : the case of al-Jamaah al-Islamiyyah and the radicalisation of the Poso conflict, 2000-2007 / Muhammad Tito Karnavian.

pages $\mathrm{cm}$-- (Imperial College Press insurgency and terrorism series ; vol. 3)

Includes bibliographical references and index.

ISBN 978-1-78326-485-8 (hard cover : alk. paper)

1. Insurgency--Indonesia--Poso (Kabupaten) 2. Radicalism--Religious aspects--Islam. 3. Ethnic conflict--Indonesia--Poso (Kabupaten) 4. Christianity and other religions--Islam. 5. Islam--

Relations--Christianity. 6. Jamaah Islamiyah (Indonesia) I. Title. II. Series: Imperial College Press insurgency and terrorism series.

HV6433.I5K 372014

959.804'1--dc23

2014029332

\section{British Library Cataloguing-in-Publication Data}

A catalogue record for this book is available from the British Library.

\section{Copyright (C) 2015 by Imperial College Press}

All rights reserved. This book, or parts thereof, may not be reproduced in any form or by any means, electronic or mechanical, including photocopying, recording or any information storage and retrieval system now known or to be invented, without written permission from the Publisher.

For photocopying of material in this volume, please pay a copying fee through the Copyright Clearance Center, Inc., 222 Rosewood Drive, Danvers, MA 01923, USA. In this case permission to photocopy is not required from the publisher.

In-house Editors: Thomas Stottor/Chye Shu Wen/Rajni Gamage

Typeset by Stallion Press

Email: enquiries@stallionpress.com

Printed in Singapore 


\section{Contents}

Acknowledgements vii

Executive Summary $\quad$ xi

Chapter 1: Introduction 1

Chapter 2: Al-Jamaah al-Islamiyyah: From Insurgency to Terrorism $\quad 39$

Chapter 3: Violence in Poso: From Armed Sectarian Conflict to Terrorism, 1998-2007 77

Chapter 4: First Causal Factor: Disaffected Persons 111

Chapter 5: Second Causal Factor: Enabling Group 131

Chapter 6: Third Causal Factor: Legitimising Ideology 161

Chapter 7: The Radicalisation Process of Muslims in Poso 187

Chapter 8: Conclusion and Policy Implications 219

Appendix: Figures and Tables 239

$\begin{array}{ll}\text { Glossary } & 257\end{array}$

Bibliography $\quad 269$

Index $\quad 281$ 
This page intentionally left blank 


\section{Acknowledgements}

In the name of Allah, Most Compassionate, Most Merciful.

First of all, I must thank Allah, the Almighty, who has empowered and enabled me to complete this thesis.

I began my PhD programme in July 2008 and did my best to complete it as fast as possible so that I could get back to work as a police colonel of the Indonesia National Police (INP). Initially, this worked well and I was able to go through the coursework in a little more than a year. Having satisfied the panel of examiners at my confirmation exercise in early July 2009, I was about to begin my field research in Indonesia when I was alerted to a terrorist attack in Jakarta on 17 July 2009. I was called by the then Chief of Police to return home to assist in the investigation. The twin bombings at the Ritz-Carlton and JW Marriott hotels affected Indonesia and beyond.

The case was soon solved and the mastermind of the attack, Noordin M. Top, the most-wanted terrorist in Southeast Asia, was killed in a shootout in Solo, Central Java. The Chief of Police promoted me to Commander of Detachment 88, the INP elite unit for counter-terrorism. Consequently, I had to divide my time between my professional assignments and the PhD project. My promotion as the top leader of Detachment 88 and the new rank of Brigadier General slowed down my $\mathrm{PhD}$ research even more since most of my time had to be dedicated to this job. The 103 terrorist arrests made during my leadership in 2010, the highest annual number ever in contemporary Indonesian history, reflects the heavy workload in that year. This number broke the record of 
98 arrests in 2003 when the police organised a full-scale investigation following the 2002 Bali bombings.

But, rather than abandoning my academic research, I adopted the attitude that when life gives you lemons, make lemonade. As the commander of this counter-terrorism unit, I had full access to allimportant sources of information and data for my projects, both open and confidential. I outlined my research proposal and discussed it with my supervisors, Prof. Rohan K. Gunaratna and Prof. Kumar Ramakrishna. Once agreed, I began to collect data with the help of a civilian assistant. The data was analysed and used in the writing of this paper, which was finalised at the end of 2011.

For this work, therefore, I would like to extend my highest appreciation to my supervisors, Rohan and Kumar, for their patience in supervising me. Their rich knowledge in the field of terrorism and counter-terrorism was undoubtedly a great help in completing my PhD programme. My gratitude is also due to Barry Desker, the Dean of S. Rajaratnam School of International Studies (RSIS), Prof. Ron Matthews, Director of the PhD programme, and all the staff who enabled me to enroll and study at this worldclass institute. Mr Desker and Prof. Matthews were also kindly tolerant in understanding my position so that I could work as Commander of Detachment 88 in Indonesia while researching for my assignment.

I place on record my sincere thanks to former Chiefs of INP, General Sutanto and General Bambang Hendarso Danuri, and also General Gories Mere, Head of Indonesia Narcotics Bureau, and General Ansyaad Mbai, Head of Indonesia National Counterterrorism Agency, all of whom have generously supported me to pursue my ambitious $\mathrm{PhD}$ and gain an academic knowledge of terrorism and counter-terrorism. I hope this knowledge will be of benefit to the INP in the future.

My debt to Sidney Jones for her kindness in sparing time to go through my draft is immense. Her advice in many discussions has enriched my work since she is one of the best experts on terrorism in Indonesia. I would also like to take this opportunity to thank Evan Laksmana, my RSIS colleague, and Radhiatmoko, my assistant, for 
their invaluable assistance in collecting data and proofreading the first draft of my thesis, on which this book is based.

Last but not least, my appreciation must go to my wife, Tri Suswati, and my children Aga, Via, and Ovan. Your ongoing support boosted my motivation to complete this $\mathrm{PhD}$ odyssey.

May God always bless us. 
This page intentionally left blank 


\section{Executive Summary}

Why do some people turn to terrorism while others from the same background and the same set of experiences do not? This is the question this study sets out to answer through examining the process of radicalisation in an Islamist insurgency. It uses the conflict in Poso in the Indonesian province of Central Sulawesi from 1998 to 2007 as a case study, with a particular focus on the role of the organisation al-Jamaah al-Islamiyyah (JI) after 2000.

The study builds on the framework suggested in Richardson's study, What Terrorists Want ${ }^{1}$ — that for terrorism to occur, there must be a disaffected set of individuals, an enabling group and a legitimising ideology — as well as communications theory to develop a new model of Islamist radicalisation. It suggests that for the legitimising ideology, in this case Salafi-jihadism, to be effectively disseminated, there must be an attractive or charismatic sender, a susceptible receiver, a powerful message, and internal and external contexts that support the transmittal. Poso was chosen as the case study because all stages of the radicalisation process are clear, and both information and individuals were highly accessible.

The study establishes that JI can be considered an Islamist insurgency, not just a terrorist organisation. This is not only because of its historical ties to the rebellions against the Indonesian state in the 1950 s but also because of its ideological antipathy to what it views as the thaghut or tyrannical post-Soeharto governments because of

\footnotetext{
${ }^{1}$ Richardson, 2007.
} 
their failure to establish Islamic law. The history of JI, based on primary documents and interviews, is used to illustrate this point.

It then gives a brief description of the Poso conflict and how several radical organisations from outside the area became involved in it. One of these was JI, whose local recruits were called Mujahidin Tanah Runtuh (MTR) after the neighbourhood in which they lived. Another was Mujahidin Kompak Kayamanya (MKK) a spin-off from KOMPAK (Komite Aksi Penanggulangan Akibat Krisis - the Crisis Management/Prevention Committee), an Islamic charity that became affiliated with a terrorist group in the Kayamanya area of Poso.

Each of Richardson's three elements is then analysed. A chapter on disaffected individuals looks at the anger of the people who joined the groups. While it finds that some of those who rose to prominence from Tanah Runtuh had direct experience with the conflict, having lost relatives or property, the losses of those who joined were not all that different from the broader Muslim population, whose views were elicited through a survey. Disaffection, then, may be a necessary but certainly not sufficient explanation of why radicalisation occurs.

A chapter on the enabling groups compares MTR (JI) and MKK (KOMPAK) and shows how much more powerful the teachings of JI were because of the militancy of their teachers from Java, the emphasis on religious instruction and indoctrination, and the careful induction procedure. JI was also far better structured than KOMPAK and had a longer-term vision.

Finally the Salafi-jihadi ideology as conveyed by JI legitimised the use of violence against the Christian community, which many Muslims continued to see as the enemy even after a government peace agreement, the December 2001 Malino I Accord, was signed.

Communications theory helps explain why JI was more successful than KOMPAK in radicalising local recruits. Both JI and KOMPAK attracted a similar pool of recruits, but MTR lasted longer, and its members engaged in far more terror attacks than its MKK counterpart. JI had the better "sender" of the message; a better thought-through "message" in terms of its ideological narrative that 
resonated strongly with the local population; appropriate channels for conveying that message, particularly through religious education lectures called taklim; and a supportive environment.

The study concludes with several policy implications:

- The first priority is to weaken the ideological narrative, making it less attractive and popular. This should involve respected ulama in pointing out the theological errors involved. A new narrative should then be constructed.

- The recruiters or "senders" of the message must also be weakened. This can take place through law enforcement if they break the law, or through co-optation.

- The recruits or "receivers" need to be neutralised through community engagement to ensure the public understands the danger of the message and the need to avoid contact. This can only be conducted if there is careful mapping done of both influential senders and vulnerable receivers.

- The methods used in radicalisation need to be tackled, both the face-to-face recruitment through taklim and the mass media, including print, broadcast and electronic media.

- Finally, analysis of the contexts in which effective transmittal of radical messages takes place is critical to understanding how elements of those contexts could be changed. 